\title{
小起伏面の分布からみたトルコ，トロス山脈の 隆起と地形発達
}

\author{
須 具 俊 彦* \\ Tectonic Deformation and Geomorphological Development \\ of the Toros Mountains, Southern Turkey Viewed from \\ Distribution of Large-Scale Low-Relief Surfaces \\ Toshihiko SUGAI*
}

\begin{abstract}
In the Toros Mountains, low-relief surfaces occupy wide area over the high ridges of about $2,000 \mathrm{~m}$ a.s.1. of the Miocene limestone. Tectonic deformation of the area was inferred by characteristic distribution of the large-scale low-relief surfaces. The surfaces are divided into two types; D (doline) type and S (smooth) type. Most parts of the low-relief surfaces of D type were formed as abrasional surfaces at the nearsea level during the Middle Miocene, though in the northern region of the mountains, part of them are recognised as depositional surfaces of platform limestone composed of calcareous algae. On the other hand, S type surface was formed $100-300 \mathrm{~m}$ below the level where D type was originally formed, after the Middle Miocene as a corrosion plain.

The present altitude of the $\mathrm{D}$ type surfaces indicates amount of uplift accumulated since the Late Miocene. In the Toros Mountains, two tectonic regions are recognized; the upwarping area in the eastern part and the northward tilting area in the western part. An uplift rate of the main riges since the Late Miocene is estimated as 0.2 to $0.8 \mathrm{~mm} / \mathrm{y}$ from the altitude of these low-relief surfaces and their estimated ages.
\end{abstract}

\section{I.はじめに}

山岳地域の地殼変動の速度や様式については, 地質学的な資料が得にくいために，現在でもわか っていないことが多い。ただし，山地の内部に， かつて海面付近で形成されたとみなしうる小起伏 面（山地の地形原面）が分布する場合には，面の 高度から山地の隆起量を推定することができる。 さらに, 面の形成年代が明らかであれば，隆起速 度を求めることも可能である。
東地中海に面するトルコのトロス（Toros）山 脈 (別名 Taurus 山脈: 図 1) には，標高 $2,000 \mathrm{~m}$ を超える高さまで小起伏面が分布しており（口絵 2 : 写真 $1 ， 2)$ ，現在は深い谷に刻まれている が，その広がりは 1 万 $\mathrm{km}^{2}$ 以上に及ぶ（図 2 )。 この小起伏面に関しては, 古くはペンク（1972） の報告がある。また, Erol (1981，1991）は，こ の山脈中に， 2 段の準平原を含む 5 段の地形面を 認め, その概要を論じた。しかし，これらの研究 には，地形面の分布や対比の根拠が示されておら

* 日本学術振興会特別研究員 (東京大学理学部)

* Fellow of the Japan Society for the Promotion of Science for Japanese Junior Scientists (University of Tokyo) 


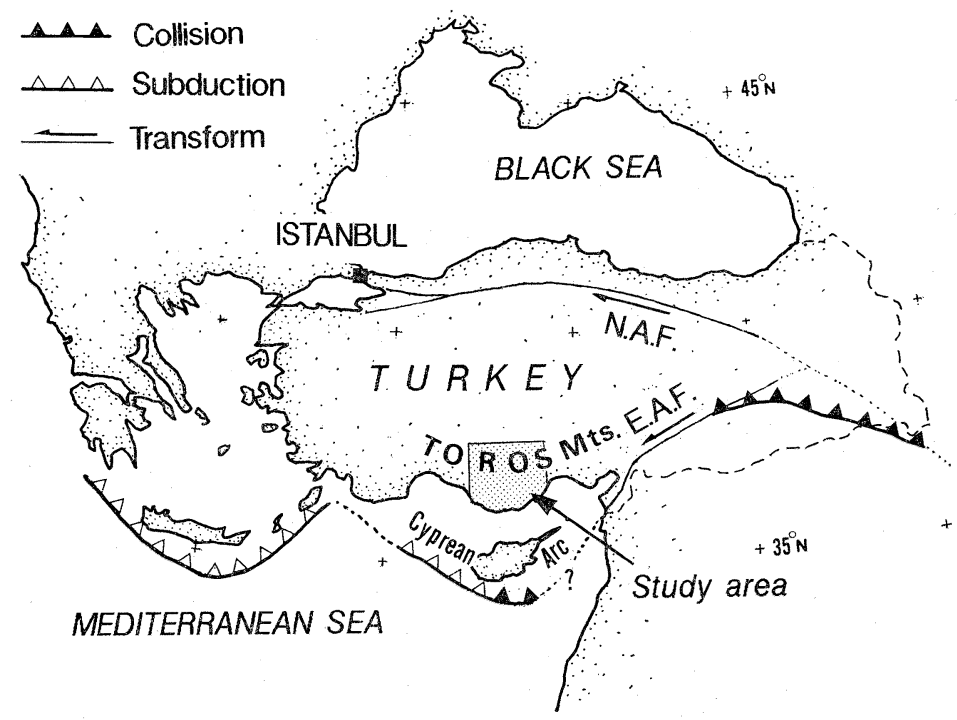

図 1 調查地域の位置

Fig. 1 Studied area in Turkey and the tectonic setting of the Cyprean Arc Zone after Dewey and Sengöl (1979) and Avraham et al. (1988)

N. A. F.: North Anatolian fault

E. A. F.: East Anatolian fault

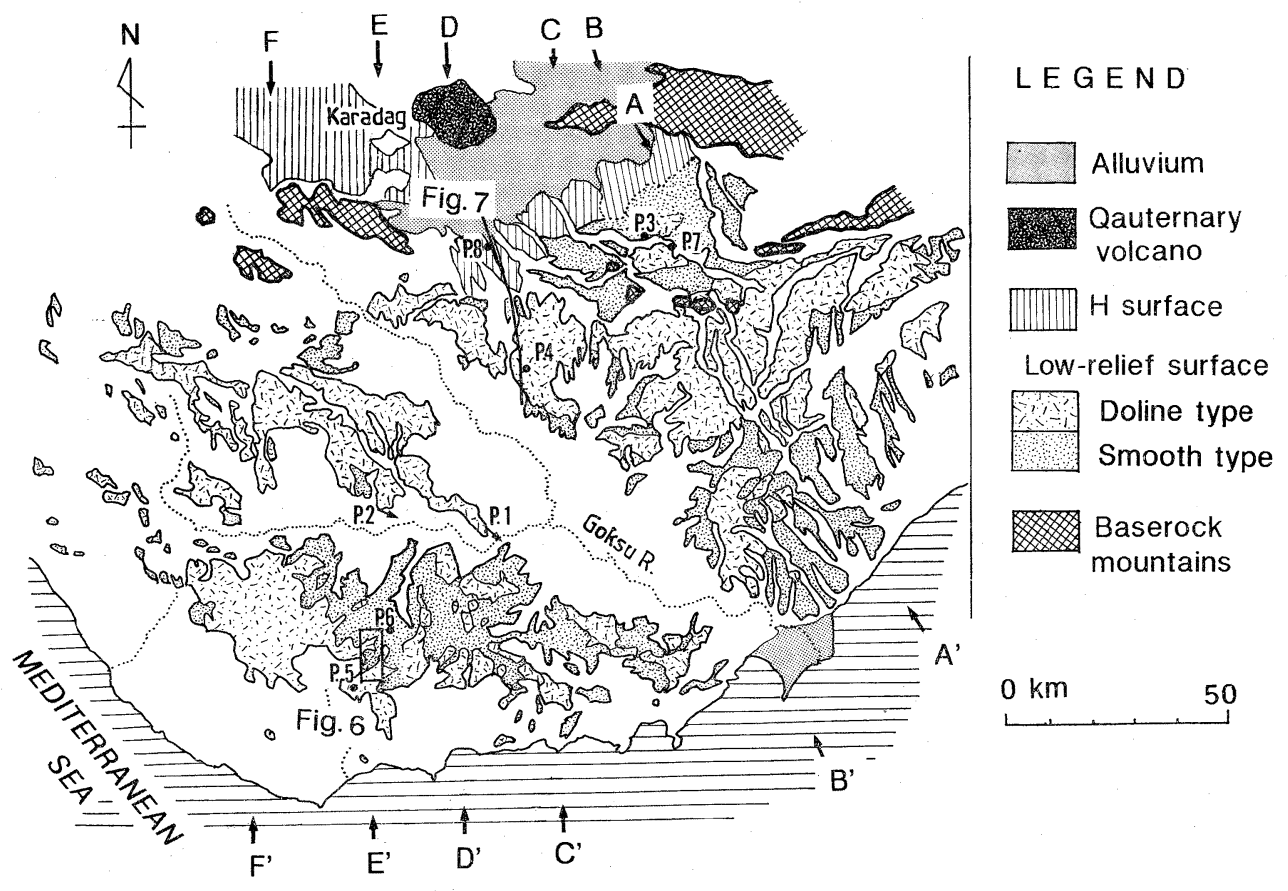

図 2 小起伏面分布図

Fig. 2 Distribution of the low-relief surfaces in the Toros Mountains P. 1-P. 8: locations of photograph 1-8 

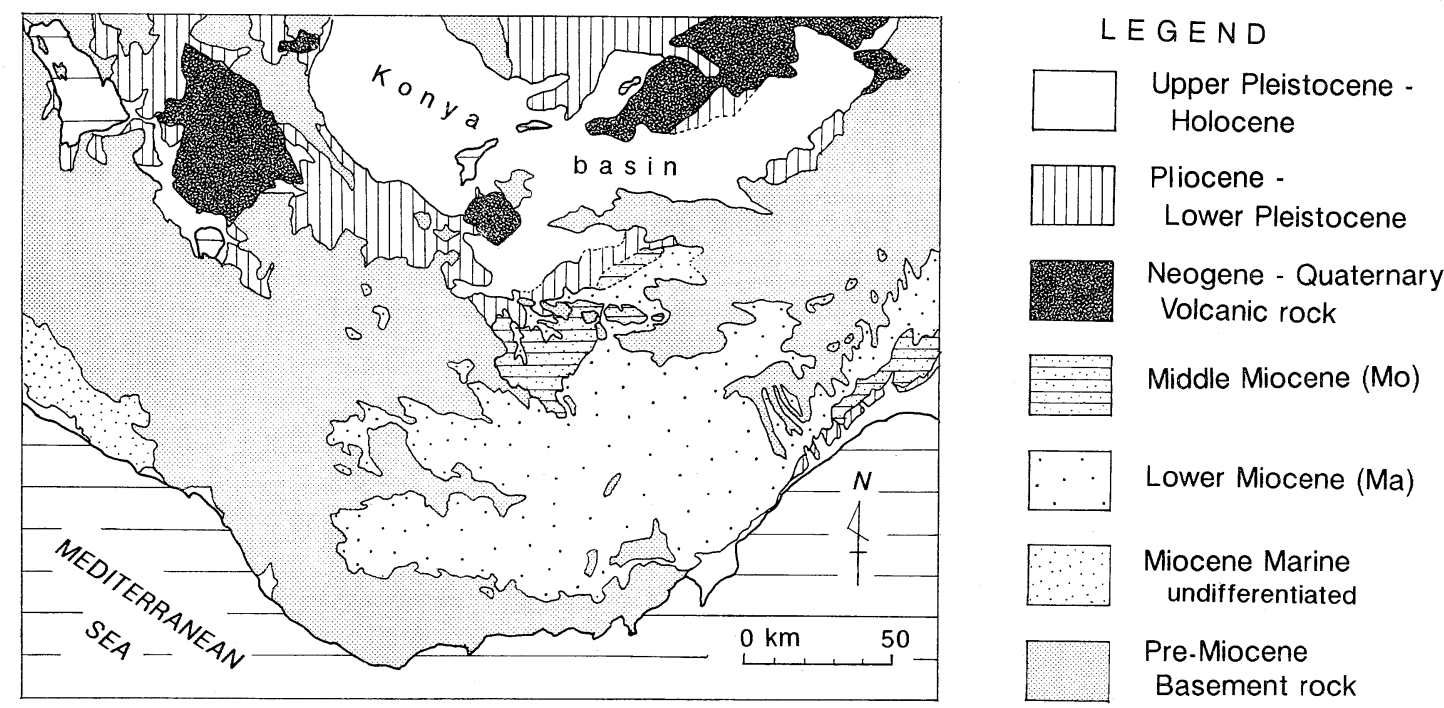

図 3 トロス山脈周辺の地質

Fig. 3 Geology around the Toros Mountains Compiled and simplified from M. T. A. (1962, 1963)

ず，地殼変動の詳細は検討されていない。

東地中海では，アフリカプレートがトルコプレ 一ト下へ沈み込んでいることが知られているが, 沈み込み带の最も東にあたるキプロス弧東部では， プレート境界の位置はよくわかっていない（Avraham et al., 1988：図 1 )。トロス山脈は，西の 沈み込み带と東の衝突带との移行域に位置してお り，トロス山脈の地殼変動を明らかにすることは， プレート境界を決める手がかりとなるばかりでな く，沈み込み带から衝突帯への時間的な変化過程 を知る上でも重要である。

そこで，本稿では，トロス山脈に発達する小起 伏面の形成過程・形成時期を検討したうえで，地 形原面とみなしうる小起伏面の分布をもとに， 卜 ロス山脈の地殼変動の速さと様式を求めてみた。

\section{II. 調査地域概観}

M. T. A. (1962，1963）の1/50万地質図（図 3 ）によると，先中新統の基盤岩類は幅 $100 \mathrm{~km}$ ほ どの東西に延びる帯状分布をなし，トロス山脈の 地形的な高まりとほぼ一致している。

山脈中央部では，ゴクス川（Goksu R.）の流 域を中心に，海成中新統が山脈を分断して内陸部
まで分布する。トロス山脈周辺の海成中新統は上 部層 (Mo, 中新世中期) と下部層（Ma，中新世前 期）とに二分されるが，Ma 上部と Mo とは， 熱帯一亜熱帯の浅海で堆積した石灰岩（platformlimestone）（口絵 $2 ：$ 写真 $3 ）$ からなり，ほたて 貝, 牡蠣, 石灰藻の化石を多量に含む。 $\mathrm{Ma}$ は 先新第三系を不整合に覆って厚く堆積しており (図 4 C-C'，D-D’), 漸新世から中新世前期にか けての大規模海進 (Steininger and Rogl, 1984) 時の堆積物と考えられている。Mo は，Ma を整 合的に覆っており，Mo 最上部には偏平な円碟が 堆積する所もある。Ma と Mo の分布域では，小 起伏面の発達がよい。

トロス山脈北麓には, 鮮新世〜更新世初期に形 成された湖成または河成の段丘面が分布する (Erol, 1978)。さらにその北側には,コンヤ (Konya）盈地が広がり，現在の盈地床は沖積平野とな っている（図 3 ）が，最終水期にはそのほぼ全域 が湖であった（Roberts，1983：図5）。また，ト ロス山脈の北にほ，山脈の高まりとほぼ平行して， 鮮新世〜第四紀の火山列が認められる。

トルコの地中海沿岸部には第四紀の海成段丘が 発達する（Erol，1985）。詳しい報告はないが，少 


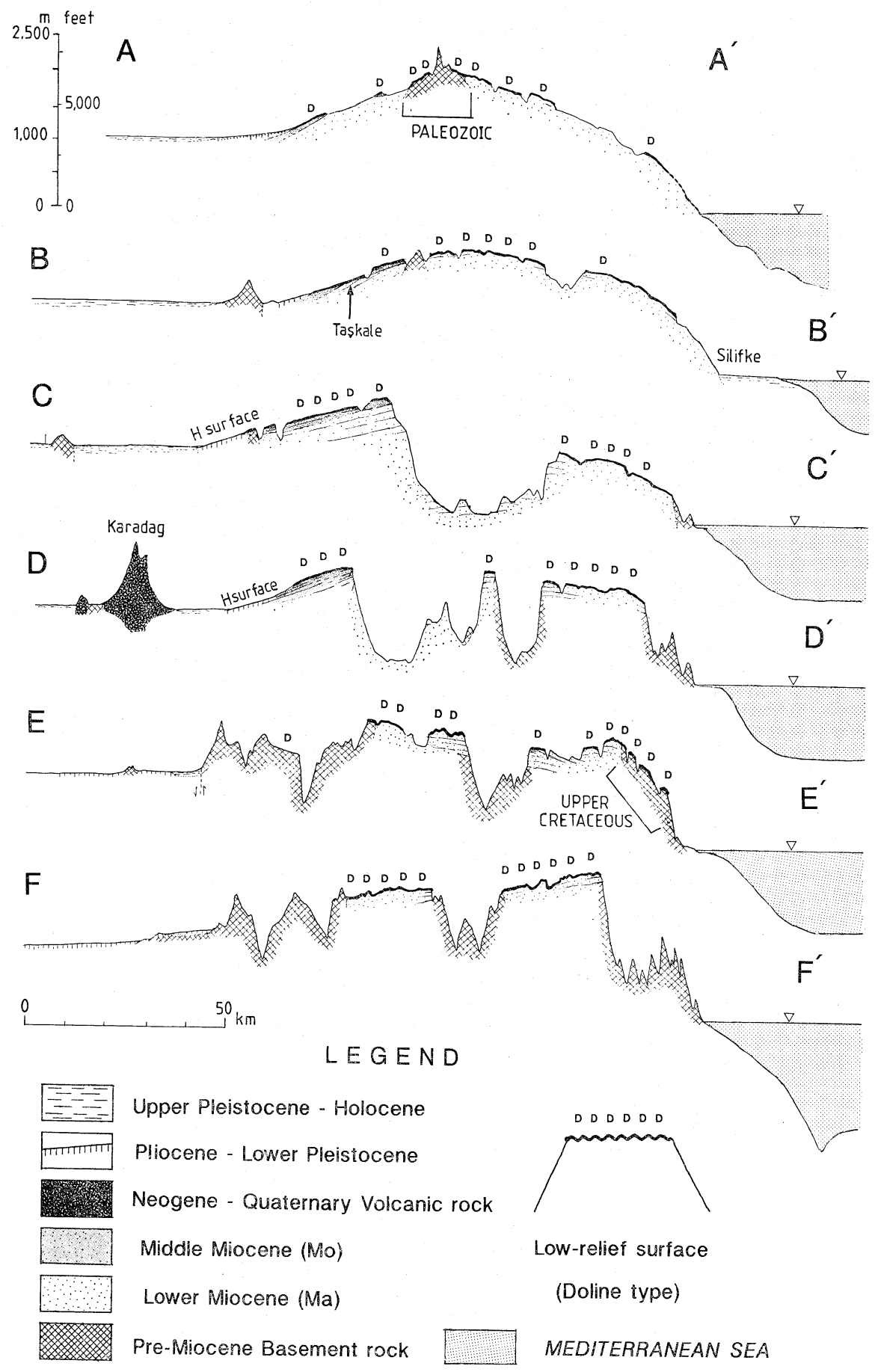

図 4 トロス山脈の地形・地質断面

Fig. 4 Geomorphological and geological cross-sections of Toros Mountains Locations of cross-sections are shown in Fig. 2. 


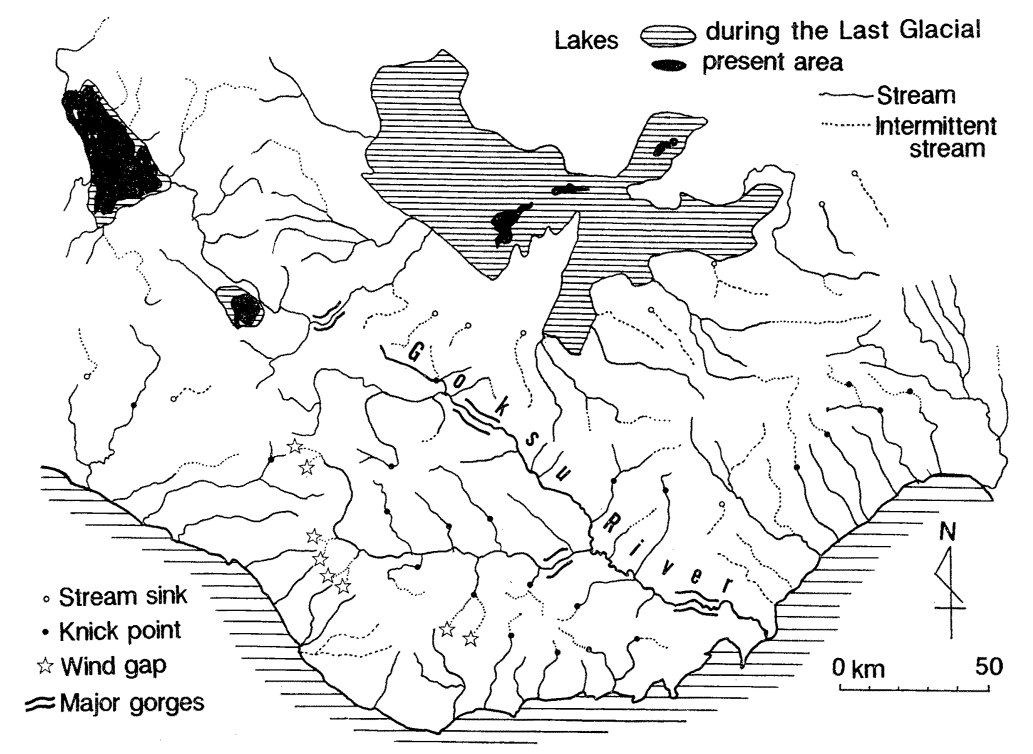

図 5 トロス山脈の水系

Fig. 5 River systems in the Toros Mountains

The extent of paleolakes are based on Erol (1978) and Roberts (1983).

なくとも2,500年前以降，海岸部では隆起も 沈降 も生じていないという (Flemming and Webb, 1986)。地中海に面するトロス山脈の南麓には, 段丘地形はほとんど分布しない。

\section{III. 小起伏面の性質と分布}

1）小起伏面の定義と認定方法

本稿では小起伏面を，「周囲がより急勾配な 斜 面（肩）によって境され，尾根上に広がる緩傾斜 地形」と定義する。

調査地域に分布する小起伏面上の起伏量は, 10 $\mathrm{km}^{2}$ につき200-300m 以下である。また，個々の 小起伏面の広がりは，10-数 $1,000 \mathrm{~km}^{2}$ に達する (図 2)。小起伏面上には，しばしば浅い谷がみら れるが，これらの谷は，下流の深い開析谷とは明 瞭な遷急点によって隔てられている。個々の小起 伏面の間には, 媣い谷が発達し, 小起伏面の縁は 比高 $1,000 \mathrm{~m}$ 前後の急崖に囲まれている。このた め, 小起伏面を遠望すると, 巨大なテーブル状を 呈する (口絵 2 : 写真 1,2 )。それゆえ, 小起 伏面と周囲の谷壁斜面との識別は容易であり，1/ 50万地形図 (Tactical Pilotage Chart) やランド
サット画像を用いても, 小起伏面の認定は可能で ある。

2）小起伏面の分類と記載

小起伏面は，表面形態の特徵により，(1) 面上 に溶蝕ドリーネが密集し, 微起伏に富むタイプ (Doline type, 以下Dタイプとよぶ; 図 $6 \mathrm{a}$, 口絵 2 : 写真 4, 5) と, (2) 起伏に乏しく平坦な夕 イプ (Smooth type, Sタイプと呼ぶ; 図6 b, 口 絵 2 : 写真 6 ）とに分類できる。Dタイプ地にお けるドリーネの分布密度は極めて高く, 20 個／ $\mathrm{km}^{2}$ を超える。 $\mathrm{S}$ タイプは侵食面の性格をもち, 孤立小丘 (hum) がみられることもある。小起伏 面の分布域 (図 2) は，中新統 (Ma および Mo) の分布範囲（図 3 ）に，その周辺の先中新統の石 灰岩類の分布範囲を加えた地域とよく一致する。 以下, $\mathrm{Mo}, \mathrm{Ma}$, 先中新統の各分布地域に発達す る小起伏面について順に記載する。

\section{Mo 分布地域に発達する小起伏面}

Mo 上の小起伏面は, Dタイプからなる（口絵 2 : 写真 4$)$ 。本面は, 他の地質地域上の小起伏 面と比べて, とりわけ平坦であり, 面の起伏量は $10 \mathrm{~km}^{2}$ につき $100 \mathrm{~m}$ 末満である(図 4 B-B', C-C', 


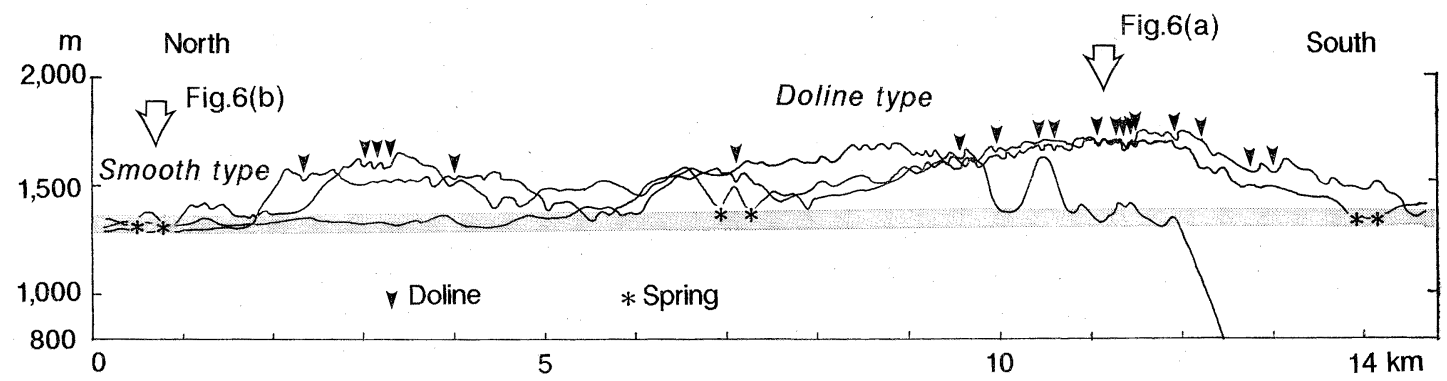

(a)

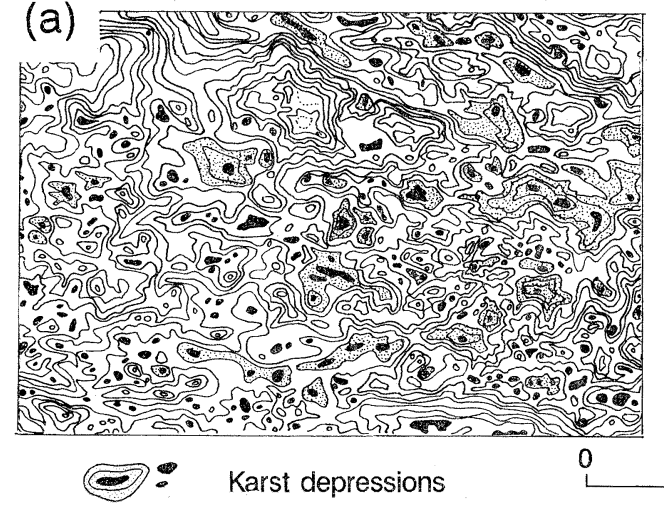

(b)

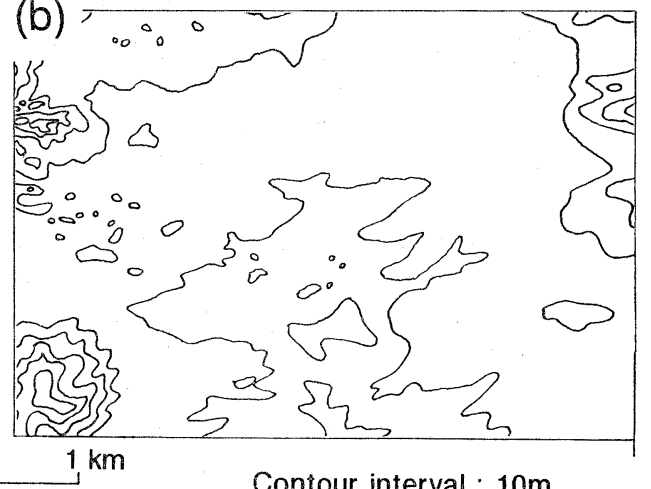

Contour interval ; 10m

図 6 小起伏面の例 （a）ドリーネタイプ(Dタイプ) (b) 平滑タイプ(Sタイプ)

Fig. 6 Geomorphic characteristics and relationship between Doline type low-relief surface and Smooth type one

Location is shown in Fig. 2.

(a) Example of Doline type surface (D type) (b) Example of Smooth type surface (S type)

D-D')。また, Mo 上に広がる小起伏面の包絡面 は, Mo 中にみられる層理面と平行し（口絵 2 : 写真 3 ), Mo と Ma との境界面とも概补平行す る。

2. $\mathrm{Ma}$ 分布地域に発達する小起伏面

$\mathrm{Ma}$ 上の小起伏面は，高低二段に分かれて発達

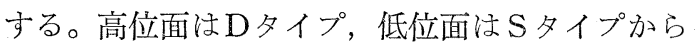
なり, 両者は比高 $200 \mathrm{~m}$ 前後の急崖によって隔て られている(図6)。Dタイプ地では，地表流はほ とんど生じない。一方, 調査地域北東部のタチカ レ (Taskale) では, 北へ傾斜する $\mathrm{Ma}$ (の層理 面）とDタイプとが，交角約 5 ○で斜交する（図 4 B-B', 口絵 2 : 写真 7) が, 他の地域では, Ma と Dタイプとは概ね平行して拈り，両者が $5^{\circ よ}$ り大きな角度で交わる例はみられなかった。また， $\mathrm{Ma}$ 上のDタイプは Mo 上のDタイプと高度的に
スムーズに連続する。とくに，山脈の北部（例え ば，図 4 B-B'のタチカレ付近）では， Ma 上の Dタイプと Mo 上の Dタイプとは平面的にも相 接する位置にあり，両者はひとつづきの小起伏面 となっている（図 $2 ， 3$ )。

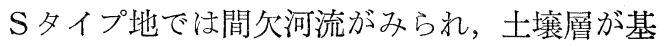
盤岩石を薄く覆っている（口絵 2 : 写真 6 )。D

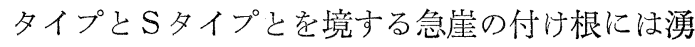
水が分布し， Sタイプ地の間欠河流の水源となっ ている。

\section{3. 先中新統上に発達する小起伏面}

先中新統分布域に発達する小起伏面は主にD夕 イプからなり（口絵 2 : 写真 5 ), 中 新統地域に 発達する小起伏面と高度的にスムーズに連続する。 例えば，山脈南部の上部白亜系分布域 (図 $4 \mathrm{E}-\mathrm{E}$ ' 南部）には，Dタイプが発達するが，この面はす 
ぐ北の $\mathrm{Ma}$ 上のDタイプに連続している。また， 山脈東部の古生層分布域 (図 $4 \mathrm{~A}-\mathrm{A}^{\prime}$ 中央部) に

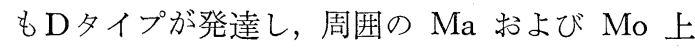
のDタイプと連続している。さらに, 古生層分布 域の中央部には，残丘状の地形がそびえて掞り (図 2,4 A-A'), ここでは, 中心より, 古生層 上の残丘状地形，古生層を切る $\mathrm{D}$ タイプ， $\mathrm{Ma}$ お よび Mo 上のDタイプといら同心円状の 分布形 態が認められる。

\section{IV. 小起伏面の形成過程と形成時期}

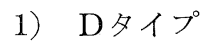

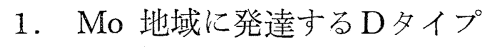

Mo 上のDタイプは深さ10-20m 程度の浅いド リーネが発達する平坦な地形面であり, その包絡 面は Mo の層理面と平行する。したがって，Mo 上のDタイプの包絡面は, Mo の堆積原面である とみなしうる。それゆえ, 面の形成期は中新世中 期と考えられる。

2. $\mathrm{Ma}$ 地域に発達するDタイプ

タチカレにおいて観察された地形面と層理面と の交差関係は，この地域の $\mathrm{Ma}$ 上のDタイプが， $\mathrm{Ma}$ の堆積構造を切って発達したことを示す。ま

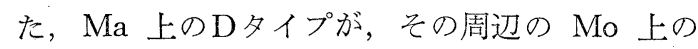
Dタイプと高度的・平面的に連続することから， 両者はほぼ同時代に同一基準面で形成されたとみ

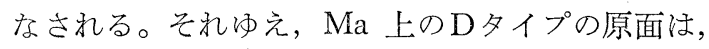
中新世中期 (Mo 堆積時) に, 海面付近の高さで 侵食(おそらく波食) を受けて形成されたと推定 される。ただし，Ma 上のDタイプと Ma の層 理面とは概衫平行している地域が多いことから， $\mathrm{Ma}$ 堆積後, Dタイプの原面が形成されるまでに, $\mathrm{Ma}$ はさほど侵食を受けなかったと考えられる。

3. 先中新統地域に発達する Dタイプ

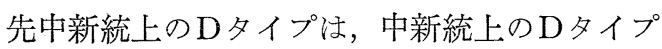
と相接する侵食面である。したがって，先中新統 上のDタイプは, 中新統上のDタイプと同時期に 海面付近の高さで，基盤山地が側方侵食されて形 成されたと考えられる。山脈東部の残丘状地形の 付け根の遷緩線は，Mo，Ma および古生層上の Dタイプの形成当時の旧汀線を示すと考える。以

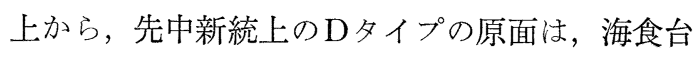
起源と考える。

4. Dタイプの起源

1.〜3. より，本地域に分布するDタイプの小 起伏面の包絡面の起源は, 中新世前期の大規模海 進に引き続く中新世中期の高海水準期に形成され た浅海底平坦面 (陸棚) であると解勫できる ${ }^{1}$ 。

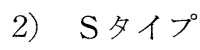

Sタイプは，Dタイプより一段低い位置に発達 する侵食面であり，Dタイプとは出入りのある急 崖によって境される。Dタイプ地域への急崖の湾 大が著しい所に涌水が集中することから, spring sapping などによる急崖の後退により， S タイプ 地が広がってきたと考えられる。すなわち，S タ イプは, Dタイプの原面形成後, spring sapping や側方溶蝕作用 (lateral corrosion) によって形 成された溶蝕平地 (corrosion plain: Ford and Williams, 1989）であると判断される。

\section{V。トロス山脈とその周辺部の地史}

1）トロス山脈北麓の段丘地形

トロス山脈北方のコンヤ盈地縁辺には，鮮新

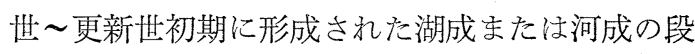
丘面が広く分布する (Erol, 1978)。本稿ではこれ を高位段丘面（H面）とよぶ2（図 7)。H面は， 石灰質細粒物からなる堆積面であり（口絵 2 : 写 真 8$)$, 堆積物中に 3 種類の陸貝化石が発見され た（ただし，殼が溶けており属種は不明：図 8)。 したがって，H面は陸上の湿地ないし湖底で形成 されたと考えられる。コンヤ盈地北縁では， $\mathrm{H}$ 面 はほぼ水平に広がり，面の標高は約 $1,050 \mathrm{~m}$ であ る。しかし, 盆地南縁 (トロス山脈北麓) では, H面は 2-3\%の勾配で北へ傾いている（図4CC', D-D', 図 6 )。

盈地を挟んで $\mathrm{H}$ 面構成層の層相や岩質に違いが みられないことから, 盈地南縁の $\mathrm{H}$ 面は, 盈地北 縁の $\mathrm{H}$ 面と同様，面の形成時にはほぼ水平であっ たが，離水後に北へ傾動したと判断される。

2)トロス山脈周辺部の地史

トロス山脈周辺では, 漸新世から中新世前期に かけて大規模な海進があり, 古い地形の起伏を埋 


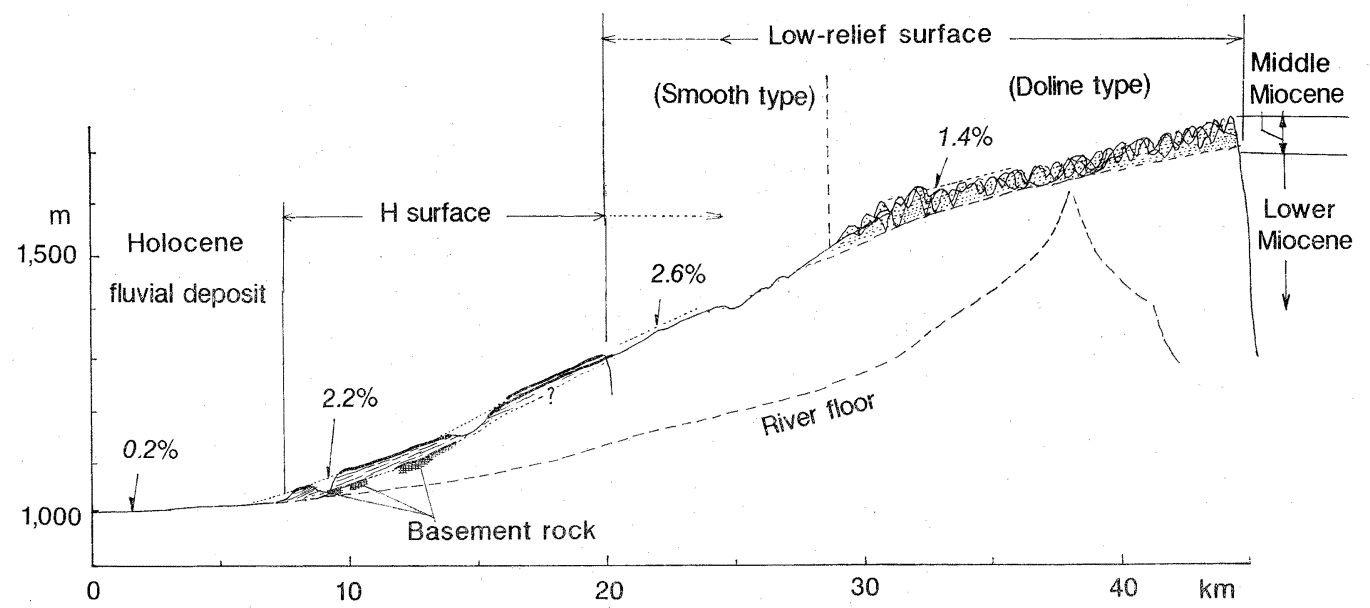

困 7 トロス山脈北麓の地形・地質断面

Fig. 7 Geomorphological and geological section crossing the northern foot of Toros Mountains. Location is shown in Fig. 2.

めながら地層 ( $\mathrm{Ma})$ が厚く堆積した (図 9 )。中 新世中期には海面が高位置で安定し，トロス山脈 の北部では浅海性の地層（Mo）が堆積した。同 時に，その周辺部では $\mathrm{Ma}$ や鮮新第三系の基盤岩 類が削られて, 海底に注広い平坦面が形成された。

$12 \mathrm{Ma}$ ころ, 北上するアラビアプレートはトル コプレートと衝突し, 北・東アナトリア断層が活 動を始めた (Dewey et al., 1986)。この頃卜口ス 山脈海面に対し相対的に隆起を開始したと考え られる。その後, 大規模な海退が起こり, テーチ ス海は消滅した(いわゆる Messinian 危機)。一方, 中部アナトリア高原では，8-2.7Ma に大規模火 砕流を伴う火山活動があり, 噴出物の量は 11,000 $\mathrm{km}^{3}$, 厚さは $360 \mathrm{~m}$ に達した (Pasquare et al., 1988)。小起伏面上では溶蝕が進み, 山脈の北麓 には対比層 (H面構成層) が堆積した。2.7Ma 以降，火山活動に質的な変化が起こり，成層火山 活動や単成火山活動が活発になり，火山列が形成 された (Pasquare et al., 1988)。このころから トロス山脈は隆起を速め, 山脈の幅が南北方向に 膨む過程で, 山麓部に位置するH面の傾動が始ま ったと考えられる。
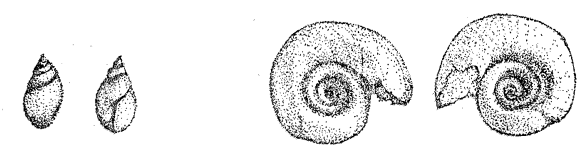

(a)
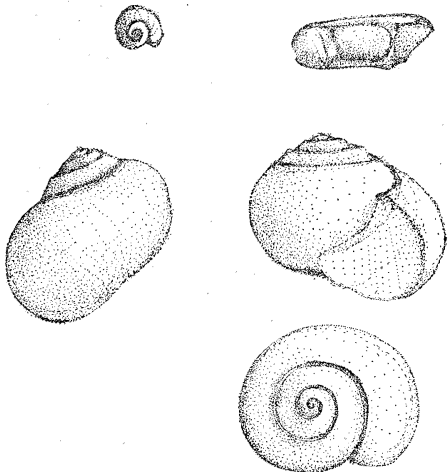

$0 \quad 1 \mathrm{~cm}$

\section{Limnic Gastropoda}

図 8 高位段丘面 (H面) 構成層から産出する陸貝 化石

Fig. 8 Three kinds of shell fossils (Limnic Gastropoda) obtained from the fine bed of the $\mathrm{H}$ surface

\section{VI. トロス山脈の隆起}

1）山脈の隆起量分布と降起様式

前述したように, Dタイプの小起伏面の包絡面 は, 中新世中期頃, ほぼ海面高度で形成されたと みなしうる。それゆえ, 現在の Dタイプの包絡面 


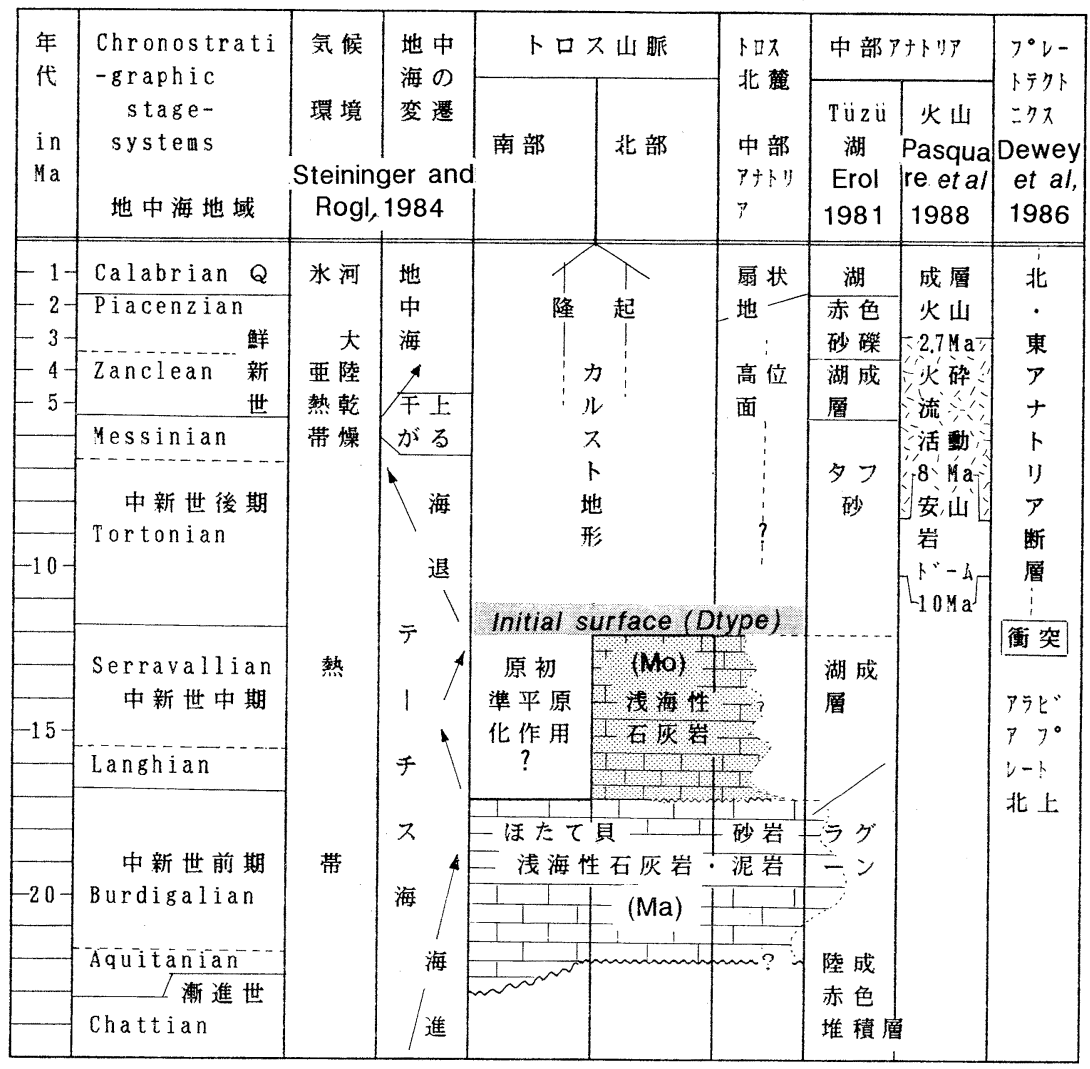

図 9 トロス山脈とその周辺部の地史

Fig. 9 Historical development in and around the Toros Mountains

の高さは, 中新世中期より後の隆起量を示すと考 えられる。そこで, $10 \mathrm{~km}$ 平方につき $1-2$ 点の 割合でDタイプの高さ（最高点高度）を読み取り, 内挿法で $200 \mathrm{~m}$ 毎の等高線を引いて，Dタイプの 包絡面の高度分布図（図10）を作成した。分布図 から，Goksu 川本流を境として，山脈の東西では 隆起様式が異なることが読み取れる。以下, 東部, 西部の順に記述する。

トロス山脈東部では，地形の骨格は長い波長の 曲隆により形成されている。隆起軸は直線的で, 東北東一西南西の走向を示し, 南西方向に僅かに $\left(0.5^{\circ}\right.$ 程度 $)$ プランジする。また，この地域の水 系は，隆起軸を分水界にもつ必従谷となっている (図 5 )。それゆえ，東部山脈は，中新世中期以降 に浅海底から出現した巨大な背斜山稯といえよう。 必従河谷に挟まれた山积には小起伏面がよく保 存され (図 2), 小起伏面の変位を連続的にとら
えることができる(例えば，図 4 A-A', B-B')。 隆起軸の北東側斜面は徐々に高度を下げながらコ ンヤ盈地へ連続する。一方, 南東側斜面は, やや 急傾斜を保ったまま地中海に没する。その延長は 大陸斜面へ連続するようである（図 4 A-A'，BB', C-C')。

トロス山脈西部では, 隆起軸は海岸に近い位置 を北西一南東方向に走っている。隆起軸の南西側 斜面と北東側斜面とでは，傾斜に著しい違いがあ り (図10), 山脈は北東一傾下しながら隆起して きたと考えられる。このために，背面の東部を流 れる Goksu 川（図10）では，本流の西側の流域 面積が東側の流域面積と比べて著しく大きくなっ たのであろう(図 5 )。

背面（山脈の北東側斜面）を刻む谷には明瞭な 遷急点が認められ (図 5)，これょり上流側には 小起伏面がよく保存されている (図2)。これに 


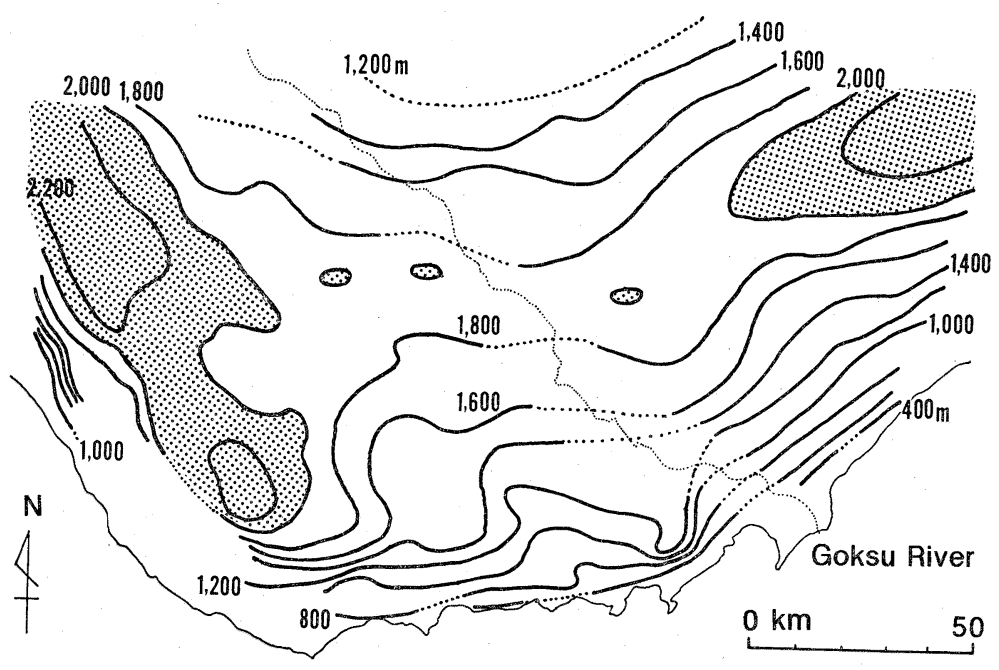

図 10 トロス山脈の隆起量分布

Fig. 10 Amount of uplift of the Toros Mountains based on the low-relief surfaces

対して，地中海に面した南西斜面では谷頭侵食が 著しく, 小起伏面上を北東へ流れる間久河川の上 流部が侵食されて, 所々に風隙（wind gap）が生 ビている(図 5 )。

上述した山脈の東西間にみられる隆起様式の違 いは，キプロス弧の東西間にみられる沈み达み様 式の違い（図 1) を反映しているものと思われる。 キプロス弧東部では，深発地震面が久落しており (Avraham et al., 1988)，キプロス弧東部は既に 衝突段階にある（あるいは非プレート境界的であ る）と考えられる。また，ト口ス山脈東部では， 浅発地震すらほとんど発生していない (Erdik et al. , 1985)。こうしたことから，トロス山脈東部 の曲隆は, 上盤（トルコ）プレートの非弾性的な 内部変形の表われなのかもしれない。一方，山脈 西部の北東への傾動運動は, キプロス弧西部にお いて，アフリカプレートがトルコプレート下い北 東方向に沈み込んでいることと調和的である。

2) 山脈の隆起開始時期之隆起速度

III章で述べたように，山脈北部のタチカレ付近 では, 小起伏面が傾動した前期中新統 $(\mathrm{Ma})$ をき って発達する。したがって, 山脈北部では, 中新 世中期に隆起運動が始まっていたと考えられる。 しかし，中新世中期の海成層 (Mo）が比較的広 範囲に堆積すること（図 3 ) や，Mo と同時代に
対比される小起伏面が広域に分布すること(図 2), ならびに，12Ma 頃に起こったアラビアプレート とトルコプレートとの衝突や， 8-2.7Ma の大規 模な火砕流活動などから，起伏を増大させるよう な隆起運動が生じるのは中新世後期 $(11.8 \mathrm{Ma})$ 以 降であると考えられる。2.7Ma 以降には，隆起軸 に平行して成層火山列が形成されるようになる。 このことは, 南北圧縮の広域応力場のもとで, ト ロス山脈の隆起が活発化したことを示唆しており, H面の傾動とも調和的である。以上から，トロス 山脈は，12Ma 以降に隆起を開始し，2.7Ma 頃か ら隆起を速めたと考えられる。

トロス山脈の隆起軸付近に分布する小起伏面の 垂直変位量は最大で約 $2,200 \mathrm{~m}$ に達する(図10)。 したがって, トロス山脈の平均最大隆起速度は,

$2.7 \mathrm{Ma}$ 以降に隆起が始安ったとすれば $0.8 \mathrm{~mm} / \mathrm{y}$, 中新世後期 (12Ma) から隆起が継続してきたと すれば $0.2 \mathrm{~mm} / \mathrm{y}$ と見積られる。つまり，山脈の 隆起の速さは $10^{-1} \mathrm{~mm} / \mathrm{y}$ のオーダーで推移してき たということができる。

\section{VII. まとめと今後の課題}

本稿では, 山地の地形原面の形成年代と高度分 布をもとに, トロス山脈の地殼変動について検討 した。その結果，（1）トロス山脈は，中新世後期 
以降， $10^{-1} \mathrm{~mm} / \mathrm{y}$ のオーダーで隆起してきたこ と，(2) 山脈の東と西とで隆起の様式が異なり, 東部では長波長の曲隆, 西部では北東方向への傾 動によって山脈が隆起してきたこと, が示された。

トロス山脈の地款変動史をより定量化するには 中新世の古地理復元と, 中新世以降の詳しい地形 編年を行なう必要がある。また, 広域テクトロニ クスの中でのトロス山脈の位置づけや, 山脈の隆 起プロセスについては今後の課題である。

\section{謝 辞}

東京大学理学部地理学教室の大森博雄助教授には終始 御指導いただいた。池田安隆助教授には現地調查の機会 を与えていただき，貴重な御助言も賜った。Bogazici 大学の Ahmet Mete Isikara 教授には研究の便宜をは かっていただいた。静岡大学地質学教室の千葉 聡助手 には化石の鑑定をお願いした。以上の方々に厚くお礼申 し上げる。本研究旅費は, Bogaziçi 大学 (Bogaziçi University, Project Number 90 HTO 231）により支給 された。

\section{注}

1）Dタイプの包絡面は, Erol (1991)の DI 面（中新 世前～中期に形成された準平原面）に対比される. し かし，トロス山脈の Dタイプは，基底に顕著な不整合 をもつ厚い陸棚堆積物（Ma 上部層㧍よび $\mathrm{Mo}$ ) 上に 広がることから，長期閒の陸上侵食によって形成され た準平原であるとは考えにくい。

2）コンヤ盈地周辺には，H面より低位の段丘面は分布 しないが、これは，コンヤ盈地は層厚 $50 \mathrm{~m}$ 以上の厚 、沖積層记覆われており (Ridder, 1965)，第四紀に は相対的沈降域にあるためと考光られている（Erol， 1978).

\section{文献}

Avraham, Z., Kempler, D. and Ginzburg, A. (1988) : Plate convergence in the Cyprean Arc. Tectonophysics, 146, 231-240.

Dewey, J. F. and Sengör, A. M. C. (1979): Agean and surrounding regions: Complex multiplate and continuum tectonic in a convergent zone. Bull. Geol. Soc. Am., 90, 84-92.

Dewey, J. F., Hempton, M. R., Kidd, W. S. F., Saroglu, F. and Sengör, A. M. C. (1986) : Shorten- ing of continental lithosphere: The neotectonics of Eastern Anatolia-a young collision zone. Collision Tectonics, Geological Society, Suppl. Bd., 19, 3-36.

Erdik, M., Doyuran, V., Akkas, N. and Gülkan, P. (1985): A probabilistic assessment of the seismic hazard in Turkey. Tectonophysics, 117, 295-344.

Erol, O. (1978): The Quaternary history of the lake basins of Central and Southern Anatolia. Brice, W., ed.: The environmental history of near and middle east. Academic Press, 111-139.

Erol, O. (1981) : Neotectonic and Geomorphological Evolution of Turkey. Z., Geomorph., Suppl. Bd., 40, 193-211.

Erol, O. (1985): The world's coastline, 68 Turkey and Cyprus. Bird, C. F. and Schwarts, M. L., eds. : The world's coastline, 491-500.

Erol, O. (1991): Geomorphological evolution of the Taurus Mountains, Turkey. Z., Geomorph., Suppl. Bd., 82, 99-109.

Flemming, N. C. and Webb, C. O. (1986): Tectonic and eustatic coastal changes during the last 10,000 years derived from archaeological data. $Z$., Geomorph., Suppl. Bd., 62, 1-29.

Ford, D. C. and Williams, P. W. (1989): Karst geomorphology and hydrology. Unwin Hyman, 601 p. M. T. A. (The Institute of Mineral research and exploration) (1962, 1963): Geological map of Turkey, scale 1:500,000, Konya and Adana sheets.

Pasquarè, G., Poli, S., Vezzoli, L. and Zanchi, A. (1988): Continental arc volcanism and tectonic setting in Central Anatolia, Turkey. Tectonophysics, 146, 217-230.

ペンク, W. 著, 町田 貞訳 (1972) : 地形分析. 古今書 院, 401p. Penk, W. (1924): Die morphologische analyse. Verlag von J. Engelhorns nachf, Stuttgart.

Ridder, N. A., (1965): Sediments of the Konya basin, Central Anatolia, Turkey. Paleogeography, Paleoclimatology, Paleoecology, 1, 225-254.

Roberts, N. (1983) : Age, palaeoenvironments, and climatic significance of Late Pleistocene Konya lake, Turkey. Quatern. Res., 19, 154-171.

Steininger, F. F. and Rögl, F. (1984): Paleogeography and palinspastic reconstruction of the Neogene of the Mediterranean and Paratethys. The geological Evolution of the Eastern Mediterranean. Geological Society, Suppl. Bd., 17, 659-668.

(1992年 4 月 30 日受付, 1992年 7 月13日受理) 